\title{
Diversity and Variability in the Preindustrial Iron-Smelting Technologies of Great Zimbabwe, Southern Africa
}

\author{
Ezekia Mtetwa
}

\section{$1 \quad$ Introduction}

The earliest Europeans to think and write about Africa, particularly subSaharan Africa, developed a narrative of uniformity, stagnancy and lack of sophistication in the social and material practices of its extinct and extant populations. Those were views that claimed that there were "... no ingenious manufactures among them, no arts, no sciences” (Hume, 1758:125). George Hegel wrote, echoing the same views later: "They have no arts, no sciences - as we see them now, so have they always been ...” (Hegel, 1840:116). James Theodore Bent, an English explorer and antiquarian who toured southern Africa at the turn of the 19 century, concluded that the iron-smelting technology of the Shona people of Zimbabwe, the primary focus of this chapter, was clumsy and replete with barbaric rituals (Bent, 1892). Again, as late as the 2oth century, some writers still doubted the very possibility and existence of African history (Roper, 1966). In general, Zimbabwe's precolonial indigenous iron-smelting technologies were dismissed as in deep and perpetual slumber, and 19th-century master smelters were scorned as turning out the same product that their ancestors had produced over the past millennia (Brown, 1973). Clearly, these views painted a picture of technological naivety and backwardness in the Zimbabwean past specifically and sub-Saharan Africa as a whole in general. Sadly, as noted by Killick (2015) and Farrar (2O2O), among others, such scientific racism continues 
today in some scholarly and popular opinions, including global political figures ${ }^{1}$ and at times, it is re-echoed by Africans themselves. ${ }^{2}$

An effect of these misconceptions on African technology was that the archaeological record of preindustrial iron metallurgy was perceived as non-existent or less diversified, particularly in areas south of the Zambezi River. The earliest bibliographical study of African metallurgy stopped at the Zambezi River, claiming a lack of relevant literature further south (Cline, 1937). The initial speculative understanding was that the classic type of iron smelting furnace south of the Zambezi was the low shaft type fired by forced draft, in contrast to the multiplicity of types in South and Central Africa (Friede, 1972; Cline, 1937; Chirikure and Bandama, 2014). The low shaft furnace has been found at iron-smelting sites dated to both the Early and Late Iron Age, and was present during colonial times, giving it a record of more than 1500 years of use between the Zambezi and Limpopo Rivers without much variation. The other type, the tall shaft furnace fired by natural draft, was thought to be confined to regions further north of the Zambezi, where they were said to be well adapted to large-scale trade in iron by their capacity and quality of smelt (Fagan, 1961). Several archaeological researchers have indeed attested their widespread existence in Zambia, Malawi and Tanzania (Mapunda, 1995; Killick, 199o).

However, mounting evidence from archaeological research across Zimbabwe reveals that the lack of technological variability and diversity claimed by earlier scholars reflect an incomplete knowledge of the archaeology of southern Africa as a whole and Zimbabwe in particular. Martin Prendergast (1975; 1979), for instance, discovered a new type of furnace suggestive of natural draft technology in the Darwendale area, northern Zimbabwe, which he dated to the 14th century AD. Here, Prendergast posits that this type of furnace was used to smelt an unusually high-grade asbestiform magnetite ore found only in the Great Dyke (Prendergast, 1979). However, the existence of this new

1 During his first visit to sub-Saharan Africa after winning power, former French President Nicolas Sarkozy made the following remarks in Senegal typical of 19th-century stereotypes: "The tragedy of Africa is that the African has not fully entered into history... They have never really launched themselves into the future... The African peasant only knew the eternal renewal of time, marked by the endless repetition of the same gestures and the same words... In this realm of fancy... there is neither room for human endeavour nor the idea of progress." https://uk.reuters.com/article/uk-africa-sarkozy/africans-still-seething-over-sarkozyspeech-idUKLo513034620070905.

2 See Humphris et al., (2009) for an example of a science teacher in Uganda overhead by a team of archaeometallurgists researching precolonial iron-smelting claiming that Africa had no science and technology before colonialism despite living close to large iron-smelting sites in his area. 
type of furnace in northern Zimbabwe was simply dismissed as an overspill of the Zambian Iron Age, rather than an artifact of broader socio-economic and technological transformations in southern Zambezia. Subsequent archaeological researches in northern Zimbabwe have illustrated that contrary to these stereotypes, pre-industrial iron technology in Zimbabwe was indeed diverse and extensive. Examples of technological variability and change in other sections of northern Zimbabwe have been recorded at such sites as Swartkrans and Baranda, showing evidence of slag tapping techniques in form of flow slag (Chirikure, 2005; Chirikure and Rehren, 2006).

This chapter uses increasing evidence from archaeological research around Great Zimbabwe to demonstrate that the record of preindustrial iron metallurgy in the area has greater technological diversity and variability than previously thought. Great Zimbabwe was at its peak as the most important political, religious and trade centre in southern Africa during the mid-second millennium AD. Despite its fame in global archaeology (Trigger, 2003; Smith, 2004), the extent of Great Zimbabwe's iron industry remained unknown and undocumented for a long time. Large areas of its wider archaeological landscape are still relatively poorly surveyed, despite more than a century of research at and around the drystone built capital. Research recurrently focused on the more archaeologically visible monumental walls and material culture within the constituent enclosures making up the urban centre of the medieval settlement (Chirikure and Pikirayi, 2008). Again, Great Zimbabwe's postcolonial era became predominated by the preservation and presentation concerns of the site, and rightly so (Ndoro, 2001). During the early phases of colonial rule in Zimbabwe, excavation activities by antiquarians left large areas of the site extensively desiccated and so other aspects of Great Zimbabwe's archaeological record are beyond reconstruction (Hall, 1909). Thus, postcolonial conservation interventions at Great Zimbabwe, which included a moratorium on further excavations within the site, made it rather difficult to explore satisfactorily the numerous angles of the site using standard archaeological methods. For instance, key aspects of the population of Great Zimbabwe have not been possible to explain in satisfactory ways, including its size (Chirikure et al., 2017), genetic composition and the whereabouts of the burial grounds of its inhabitants (Mtetwa et al, in preparation) ${ }^{3}$

In light of the research restrictions on the main site of Great Zimbabwe and the knowledge gaps of the settlement, I employed a lateral thinking

3 In 2018, the author initiated an ongoing project on the whereabouts of Great Zimbabwe burial grounds, and a report publishing results and radiocarbon dates of a much richer mortuary record is forthcoming. 
methodology between 2012 and 2017, during which I looked away from the impressive drystone walls to the iron-smelting debris in the wider landscape. Archaeometallurgy, the study of metal production in the past, has come of age as a sub-discipline of archaeology in exploring not just material properties and chemical reactions, but also the social history of our human past (Herbert, 1984; Chirikure, 2015). Within Great Zimbabwe's political and economic system, and an estimated population of around 10 ooo inhabitants (Chirikure et al., 2017), the demand for iron would have been very high and the metal consumed in a wide range of social contexts. Like in many societies of sub-Saharan Africa, iron in Great Zimbabwe was critical for its use in daily utilitarian activities such as cultivation and clearance of agricultural fields, but also in ritual and power negotiation relations (Childs and Killick, 1993; Chirikure, 2007; Herbert, 1996).

Agro-pastoral and metalworking populations were present in the Great Zimbabwe cultural landscape by the mid-first millennium AD (Chirikure, Pollard et al., 2013) a phenomenon attested in many parts of southern Africa (Mitchell, 2002). From the end of the first to the mid-second millennium AD, the rest of southern Africa experienced major technological and sociopolitical transformations generally associated with the origins of social complexity, urbanism and early state systems (Manyanga et al., 2013). These changes included an exclusive lifestyle of building monumental capitals in drystone architecture and specialised production of materials and artifacts for local consumption and trade, intensifying links with distant parts of the world (Chipunza, 1994; Pikirayi, 2013). Local metals such as gold and iron, as well as wildlife resources in the form of ivory and, possibly, skins of royal animals were exchanged with imported ceramics, beads, clothes and other trinkets in the Indian Ocean and central African trade systems (Chirikure, 2014; Wood, 2012; Swan, 2008). There is revived discussion regarding the impact of such connections and disconnections on the rise and collapse of social complexity in southern Africa as a whole and Great Zimbabwe specifically (Pwiti, 1991; Moffett and Chirikure, 2016; Pikirayi, 2017).

So far, only the iron production debris within the dry-stone-built capital has received enviable research attention (Herbert, 1996; Miller, 2oo2; Chirikure, 2007; Foreman et al., 2017; Bandama et al., 2016). However, until the nature and organisation of iron metallurgy in the hinterland of the Great Zimbabwe settlement is known, the archaeological meaning of remains within the urban centre itself remains largely diminished and incomplete. Thus, this paper uses results of previous and recent archaeological surveys and excavations conducted in areas surrounding the medieval urban centre to draw a richer account of its iron-smelting technologies. I have chosen to focus on macroscopic attributes 
of such archaeometallurgical data sets as multiple-fused tuyeres, tap slag and clusters of large circular furnace bases, including one with a unique rectangular morphology. Clearly, the growing corpus of data underpinning greater technological variability and diversity raise critical questions regarding how social changes shaped and were reshaped by iron-related practices in the history of Great Zimbabwe. In other words, exploring the nature and organisation of iron technology in the Great Zimbabwe area offers another way of looking into the everyday social life of its inhabitants, overshadowed by a focus on its spectacular monumental architecture. Aspects of these questions are addressed in detail in several papers that explore the multifaceted archaeologies of iron in Great Zimbabwe (Mtetwa, 2017). Detailed technological analyses of the recovered slags and metallurgical tuyeres are also published elsewhere (Mtetwa, in preparation; Mtetwa and Lindahl, in preparation).

\subsection{The Physical Landscape of Iron Production in Great Zimbabwe}

Great Zimbabwe (Figure 5.1), which is situated on the southern margin of the Zimbabwe Plateau, is surrounded by mountain ranges such as Nyanda and

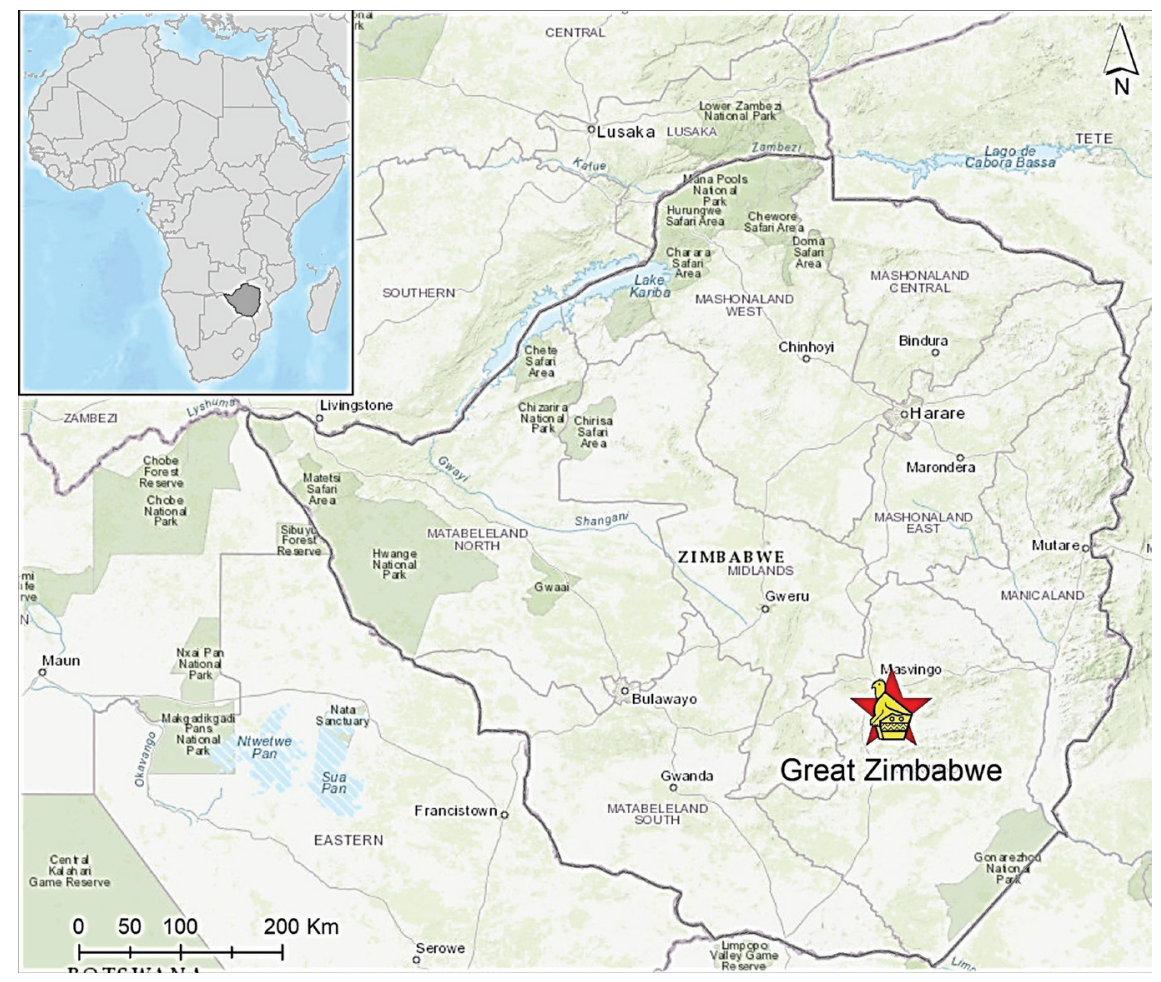

FIGURE 5.1 Map of Zimbabwe showing the location of Great Zimbabwe in Southern Africa 
Ruvhuri to the west, Beza and Nyuni to the north, as well as Chigaramboni to the southwest. These mountain ranges are rich in banded ironstones (Lister, 1987). Presumably, these iron-rich ores sustained pre-industrial iron metallurgy in the area (Mtetwa, 2011; Ndoro, 1994), as evidenced by modern iron ore mining in the Nyuni Hills (Mapira, 2012). In addition, areas near the Bondolfi Mission $15 \mathrm{~km}$ northwest of the Great Zimbabwe centre have rich gold deposits, which supported precolonial gold mining (Phimister, 1976; 1974) and continue to be exploited today. Great Zimbabwe's whalebacked granite outcrops provided natural platforms for crushing iron ore, a practice observed by Carl Mauch, a German explorer who visited Great Zimbabwe in the 1870s (Burke and Mauch, 1969). There are numerous dolly holes around the Great Zimbabwe area attesting to such symbiotic relations between the physical environment and the processing of mineral ores, among other functions.

In addition, the Great Zimbabwe area is relatively well favoured by Zimbabwe's savanna climate rainfall, which is often unpredictable. Much of the rain comes in the form of mist, locally known as guti, which, together with its numerous natural springs, make the Great Zimbabwe area a water-rich landscape that supports the production of grain and other crops (Bannerman, 1982; Pikirayi et al., 2016). This microclimate sustains deciduous miombo savanna woodlands, which would have been exploited by its populations for timber, medicines, domestic fuel and, importantly, charcoal for metallurgical activities (Ndoro, 2001). Anthracological analysis of charcoals recovered from furnace pits in the Chigaramboni iron-smelting sites indicate that such tree species as Acacia robusta, Acacia sieberiana, Acacia xanthophloea, Acacia polyacantha, Acacia burkei, Faurea saligna, Schotia brachypetala, Kigelia africana and Parinari curatellifolia were exploited in the iron industry (Chikumbirike, 2014). The narrow valleys between the numerous bornhardts and whalebacked hills common in the area have cultivable and very fertile loamy soils, adding to the natural resources that would have attracted agro-pastoral populations to flourish in this area over time.

\subsection{Archaeological Surveys and Excavations: A Brief Note}

Earlier investigations, particularly between the 1970s and 1990s, sought to examine state formation processes and settlement patterns around the Great Zimbabwe centre (Ndoro, 1994; Sinclair, 1987; Sinclair, 1984). In the process, these researches encountered and made reports of considerable iron production debris, which have received very little archaeological attention. The most recent investigations, undertaken as components of my Masters and Doctoral projects between 2010 and 2016, aimed to achieve three specific objectives. First, the fieldwork in 2010 sought to establish technological parameters of an 


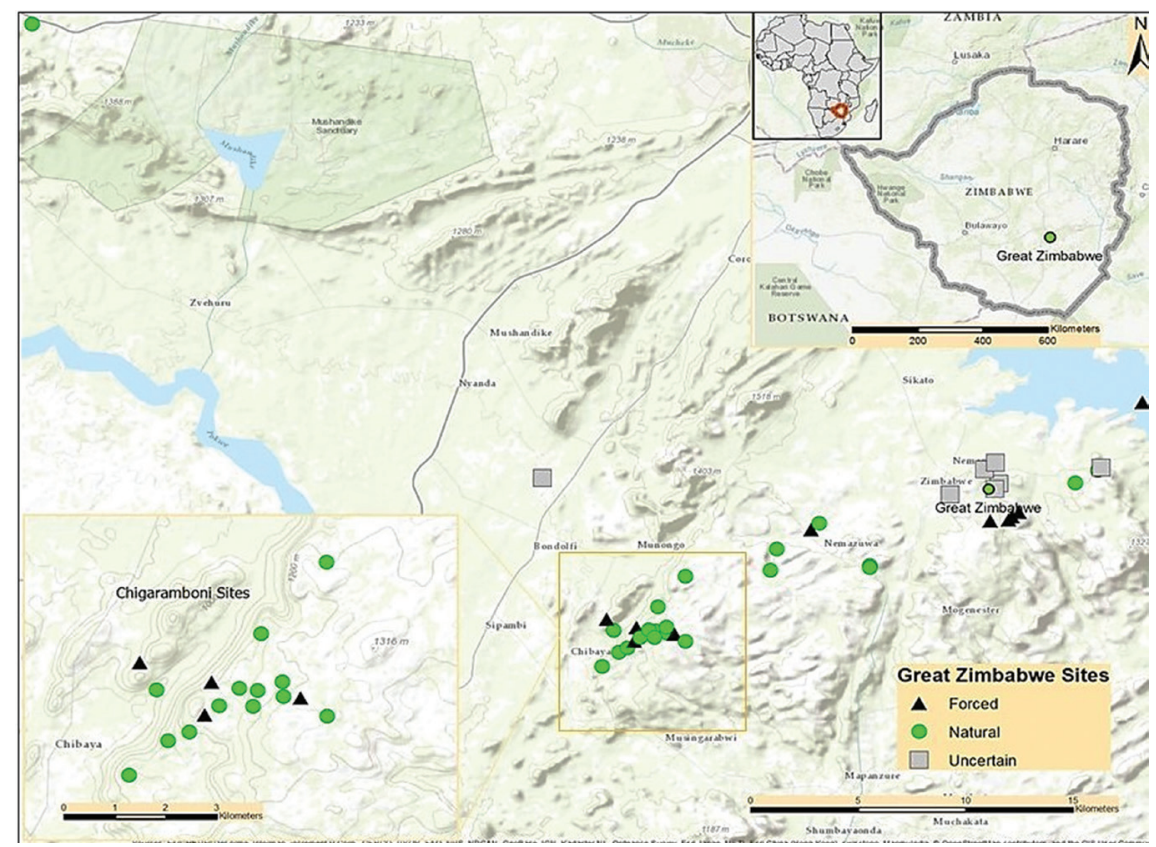

FIGURE 5.2 The distribution of iron production sites in the wider Great Zimbabwe landscape

iron production site threatened by the Gaths Mine chrome prospecting activities in Mashava (Mtetwa, 2011). The second fieldwork, between 2013 and 2016, aimed to identify previously undocumented iron-working sites and confirm others reported by previous researchers; examining their wider implications in the archaeology of Great Zimbabwe (see the distribution and concentrations of sites recorded sites in Figure 5.2). Finally, the investigations aimed to recover high quality remains of iron production from the best-preserved and technologically most representative sites for subsequent reconstructions of the iron technology itself, but also aspects of the environment and radiometric dating.

\section{Results}

Forty-two iron production sites were recorded during the recent field surveys (see Figure 5.2 and Table 5.1). Four of the sites were excavated during the course of my PhD study, bringing the total number of excavated sites around Great Zimbabwe to six after the respective works of David Collett at Goose Bay in 1986 and Webber Ndoro at Chigaramboni in 1991. This section presents examples of the recovered materials from these excavations, including samples from 
surface collections at two other sites that could not be excavated due to limited time and funding. Results of the detailed laboratory analyses conducted on the recovered materials, as pointed out before, are published elsewhere. Only the macroscopic attributes of remains from eight sites are dealt with in this paper to draw an initial picture of yet another category of technology associated with Great Zimbabwe, apart from the famous drystone architecture.

\subsection{Chigaramboni}

The Chigaramboni cluster of iron production sites is located $15 \mathrm{~km}$ southwest of the medieval Great Zimbabwe urban centre. Initially investigated in 1991 by Webber Ndoro (1994) and this author recently, the majority out of a total of 15 recorded sites are characterized by concentrations of large furnace bases, heaps of multiple fused tuyeres and slags (Figure 5.3). Ndoro's excavations uncovered furnace pits measuring about $1.4 \mathrm{~m}$ in internal diameter, which were also lined inside. These furnaces occur in clusters at the various recorded sites around Chigaramboni hills as evidenced by the visible circular furnace bases showing on the ground in association with large heaps of tuyeres. He noted that the biggest site, for instance, carried at least ten large heaps of tuyeres in association with at least five visible furnace bases (Ndoro, 1994), suggestive of large-scale iron production.
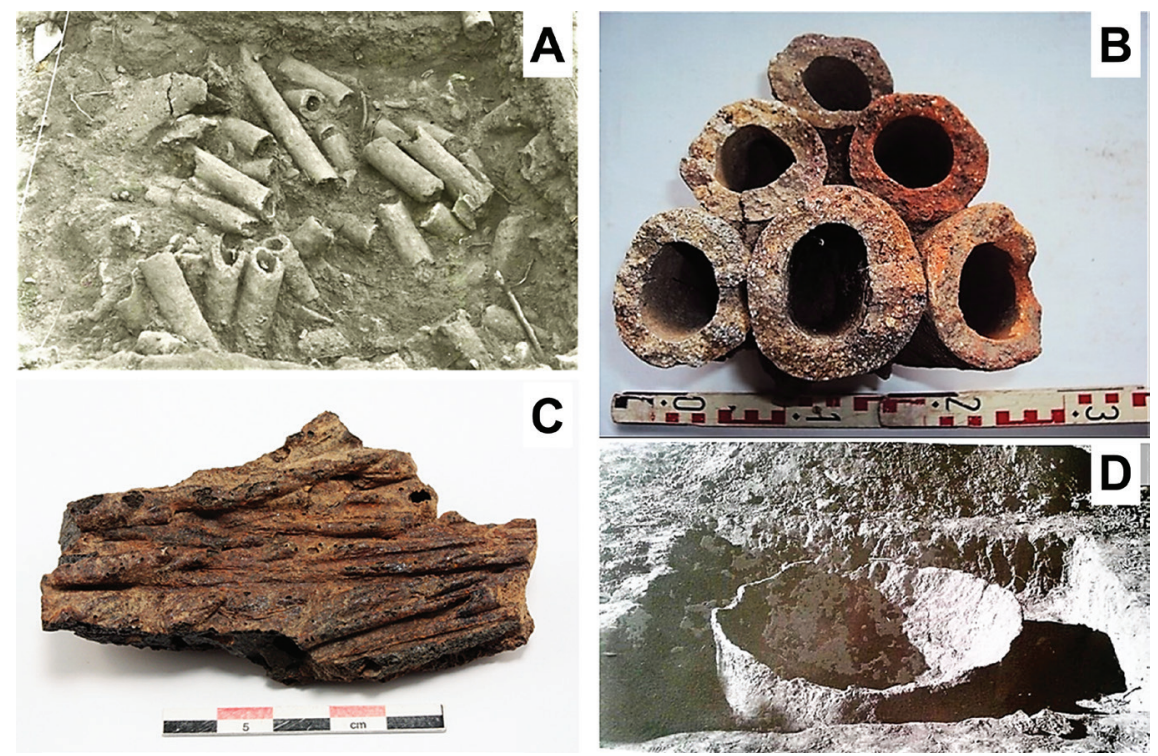

FIGURE 5.3 Archaeometallurgical materials from Chigaramboni site: (A) A heap of excavated tuyeres; (B) Tuyeres fused in multiples; (C) Furnace slag with plant impressions; (D) A furnace pit with lining 
Many of the tuyeres at the Chigaramboni sites are fused together, ranging from two up to ten pipes (Figure $5 \cdot 3 \mathrm{~B}$ ), a feature known elsewhere which underpin the use of natural draft air-supply mechanisms (Prendergast, 1975; Killick, 1991). The tuyeres average about eight centimetres in external diameter and five centimetres internal diameter on both ends, allowing much air to be blown into the furnace for intense heating (Rehder, 2000). They also show signs of vitrification and sintering, causing the tuyere pipes to fuse together. There is no evidence of a settlement in the immediate vicinities of the smelting sites, possibly highlighting the influence of mineral and wood fuel resources in the location of smelting activities. Owing to its absence in the ethnographic and written accounts of Zimbabwean iron metallurgy, the natural draft technology from Chigaramboni sites is dated relatively to before $1800 \mathrm{AD}$ (Ndoro, 1994).

\subsection{Mashava}

Mashava site lies about $40 \mathrm{~km}$ west of the Great Zimbabwe urban centre. The area falls under Gaths Mine, which currently extracts chrome and asbestos from the southern ends of the Great Dyke. The high concentration of iron production debris at the site, divided into two clusters by a seasonal stream (Figure 5.4A), suggests large-scale iron production beyond subsistence consumption. These metallurgical remains are in the form of at least twenty visible furnace features, massive and dense slag, heaps of tuyeres and possible quarries of magnetite iron ore. Some of the slag pieces at the site are tuyeremoulded (Figure 5.4B), showing the cylindrical shape of the tuyeres into which the molten slag flowed and solidified. Other slag pieces show a clear flow texture
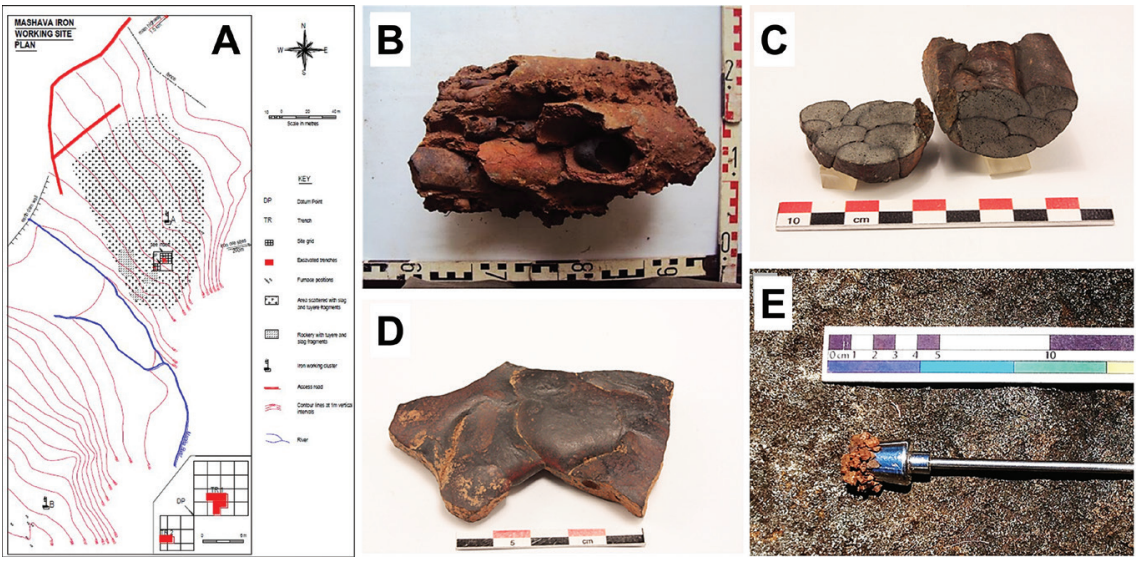

FIGURE 5.4 Archaeometallurgical materials from Mashava site: (A) Mashava site plan

(B) Tuyeres fused in multiples; (C) Tuyere-moulded slag; (D) Tap or flow slag;

(E) Magnetite iron ore 
in the form of wrinkled red-brown surfaces and sand impression underneath (Figure 5.4C), which typically indicates slag tapping practices (Killick, 1990; Chirikure and Rehren, 2006; Miller et al., 2001). Five tuyere pieces were found fused together, clogged inside and coated on external surfaces with slag, while others were completely collapsed, vitrified and eroded away around the mouth due to intense heat inside the furnace. Macroscopically, the tuyeres and furnace blocks have visible coarse quartz sand, which raises questions regarding the nature of soils selected for the manufacture of metallurgical ceramics and fluxing techniques adopted at Mashava site (Mtetwa and Lindahl, manuscript).

About 200 m east of the smelting site, there are shallow depressions in which are found scatters of a highly magnetic magnetite iron ore, which presumably supported iron production activities at Mashava site. Detailed laboratory analyses of the presumed iron ore, slags, and crown materials will shed more light on this possibility as well as illuminating the complexity and sophistication of the designs and processes of iron production at Mashava site (Mtetwa, in preparation). Owing to a dearth of diagnostic material culture, the period of the site could not be established by relative dating and further excavations are expected to recover charcoal samples for radiocarbon dating.

\subsection{Mutevedzi}

Mutevedzi site (also known as Nezvigaro) is located $6 \mathrm{~km}$ south-west of Great Zimbabwe World Heritage Site. It is located on a pass some $200 \mathrm{~m}$ away from Shambinyara, a perennial stream that would have supplied water for metallurgical purposes at the site. The site consists of a dense scatter of slag, tuyere fragments and furnace rubble spread across an area covering 3 hectares. Excavations of a less disturbed section of the site revealed a rectangular furnace base measuring about $2 \times 1 \mathrm{~m}$ (Figure 5.5). The blocks of the broken furnace wall, which measure about $10 \mathrm{~cm}$ thick on average, have visible finger impressions and evidence of vitrification. As mentioned before, the furnace blocks lack the typical curvilinear shape common with most iron smelting furnaces in African iron metallurgy, further confirming that the sides of the superstructure, like the base, were rectilinear. The floor of the furnace slopes gently northwards and its southern end was destroyed.

At least twenty near-complete tuyeres pieces were found in association with the rectangular furnace, averaging $25 \mathrm{~cm}$ in length, about $4 \mathrm{~cm}$ in internal diameter and $6 \mathrm{~cm}$ external diameter, showing signs of vitrification at the distal end. At least three tuyeres were found fused together, suggesting the possible use of natural draft air-supply mechanisms to drive the furnace. The slag recovered from the excavation had very high porosity and plant impressions, with some of them exhibiting near-straight edges from the linear shape of the 


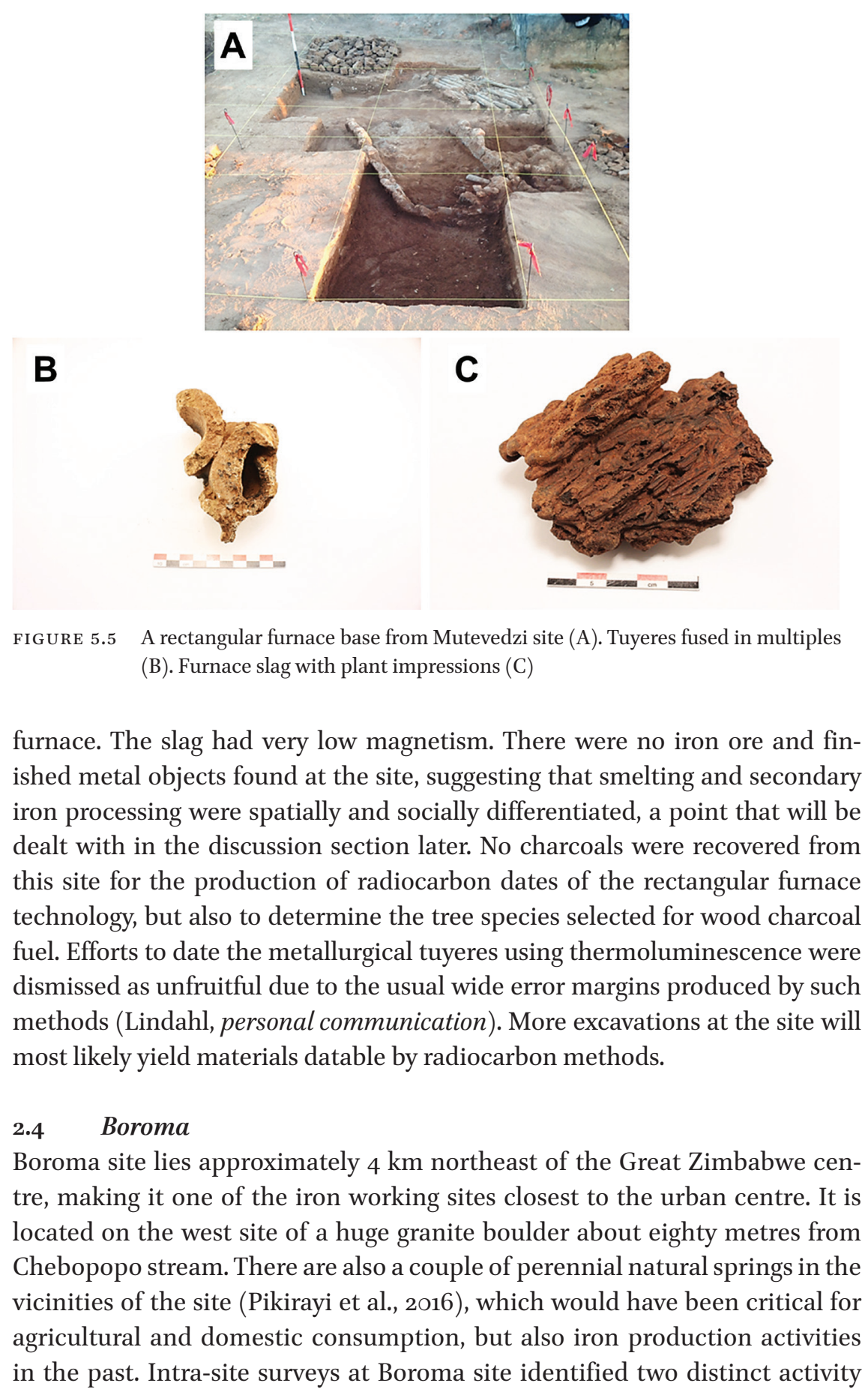


areas -iron smelting and smithing locations, the latter in association with house foundations.

Archaeological excavations at Boroma Site recovered iron smelting slag, broken tuyere pieces, blocks of furnace rubble, and charcoals. The bulk of the slag was made up of large cake-like blocks, the largest one measured about $15 \times 13 \mathrm{~cm}$ with a thickness of about $7 \mathrm{~cm}$. Some of the recovered slag blocks had plant impressions and bone inclusions, which would have been significant components of the bloomery recipes, as observed elsewhere (De Caro, et al., 2013; Prendergast, 1974). At least 30 broken tuyere pieces measuring at most $15 \mathrm{~cm}$ in length were recovered from one of the excavated trenches. Four broken tuyere pieces were fused together, suggesting that the smelting process used natural draft technology to drive the furnaces. Both single and multiple-fused tuyeres exhibited evidence of vitrification and collapse at the mouth (Figure 5.6), indicating the intense heat generated during the smelting process.

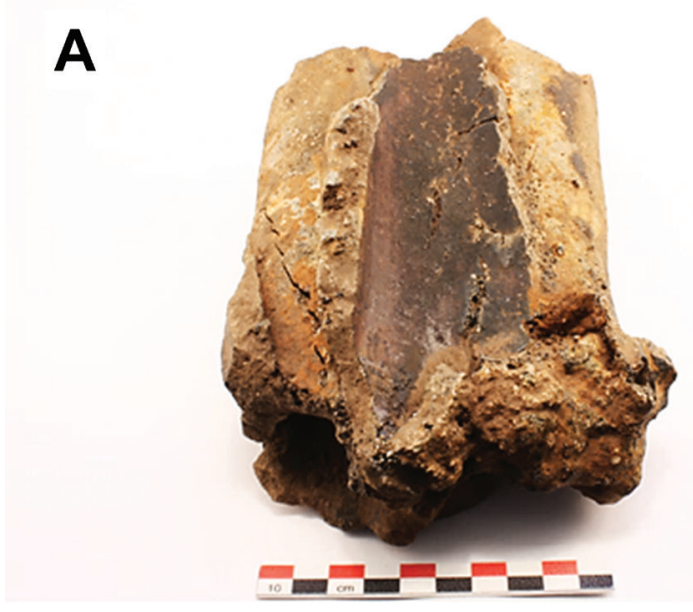

\section{B}

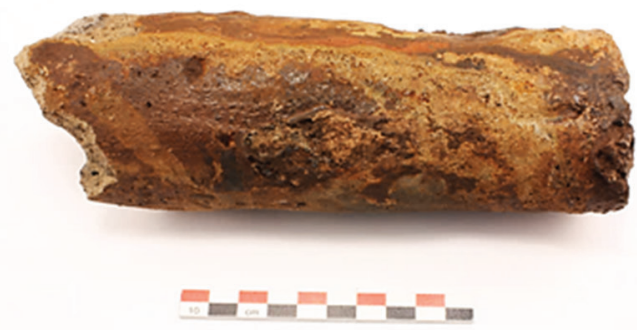

FIGURE 5.6 Multiple fused tuyeres (A). Single tuyere (B) 
The internal diameter of the different tuyeres recovered at Boroma site ranged between 30 and $40 \mathrm{~cm}$, while their external diameters measured between 50 and $60 \mathrm{~cm}$, showing a very fine brick-red fabric.

The site also consists of remains of iron smithing activities in the form of a possible smithing hearth, slags, and flat surfaced granite block located less than $200 \mathrm{~m}$ further west of the smelting area. Isolated domestic artifacts such as a piece of green and white chinaware, a potsherd with cross hatched lines and an iron hoe blade were collected from the cultivated land between the smelting and smithing areas. These were too few to shed adequate light towards our understanding of the period of occupation and the contemporaneity of the settlement and ironworking activities.

Boroma iron production site has been radiocarbon dated to $1058 \pm 28$ в (Ua- Ua-54052) using charcoals recovered from the furnace pit (Table 5.1), making the site possibly one of the earliest sites associated with natural draft technology in southern Africa. More research at the site is required to verify this date, which has the potential to refine our understanding of the chronology and distribution of natural draft technology in African iron metallurgy.

\subsection{Veza $A$}

The Veza A iron-working site is located about $8 \mathrm{~km}$ south-west of Great Zimbabwe. It is situated at the foot of the western slope of a large granite inselberg and is bounded on the south by the Veza River about 100 metres away, which would have supplied water for the iron production activities at the site. Right within the site is an abandoned modern homestead whose flowerbeds and courtyard were demarcated using finger-impressed and vitrified blocks of broken furnace walls. Other furnace blocks and dense pieces of slag (measuring approximately $20 \times 15 \mathrm{~cm}$ ) were used to stabilize soil on top of the graves belonging to members of the family that settled within the site in recent times. Many more blocks of slags, furnace rubble and pieces of tuyere were cleared from the land surrounding the homestead in preparation for maize cultivation and made into large heaps on the edges of the fields. Pedestrian surveys around the site identified more iron production debris towards the top of the granite inselberg about $800 \mathrm{~m}$ east of the main site. The site has a dense scatter of iron slag over an area of about 3 hectares.

Excavations at the site uncovered a possible semi-circular furnace wall measuring $100 \mathrm{~cm}$ in diameter, with a plastered base tilting westward gently (Figure 5.7). The western section of the furnace wall had been totally removed, most probably, by the ancient metallurgists themselves as a way of harvesting the bloom from the furnace chamber. A possible rake channel was also exposed sloping down to the west from the furnace measuring another one metre, 

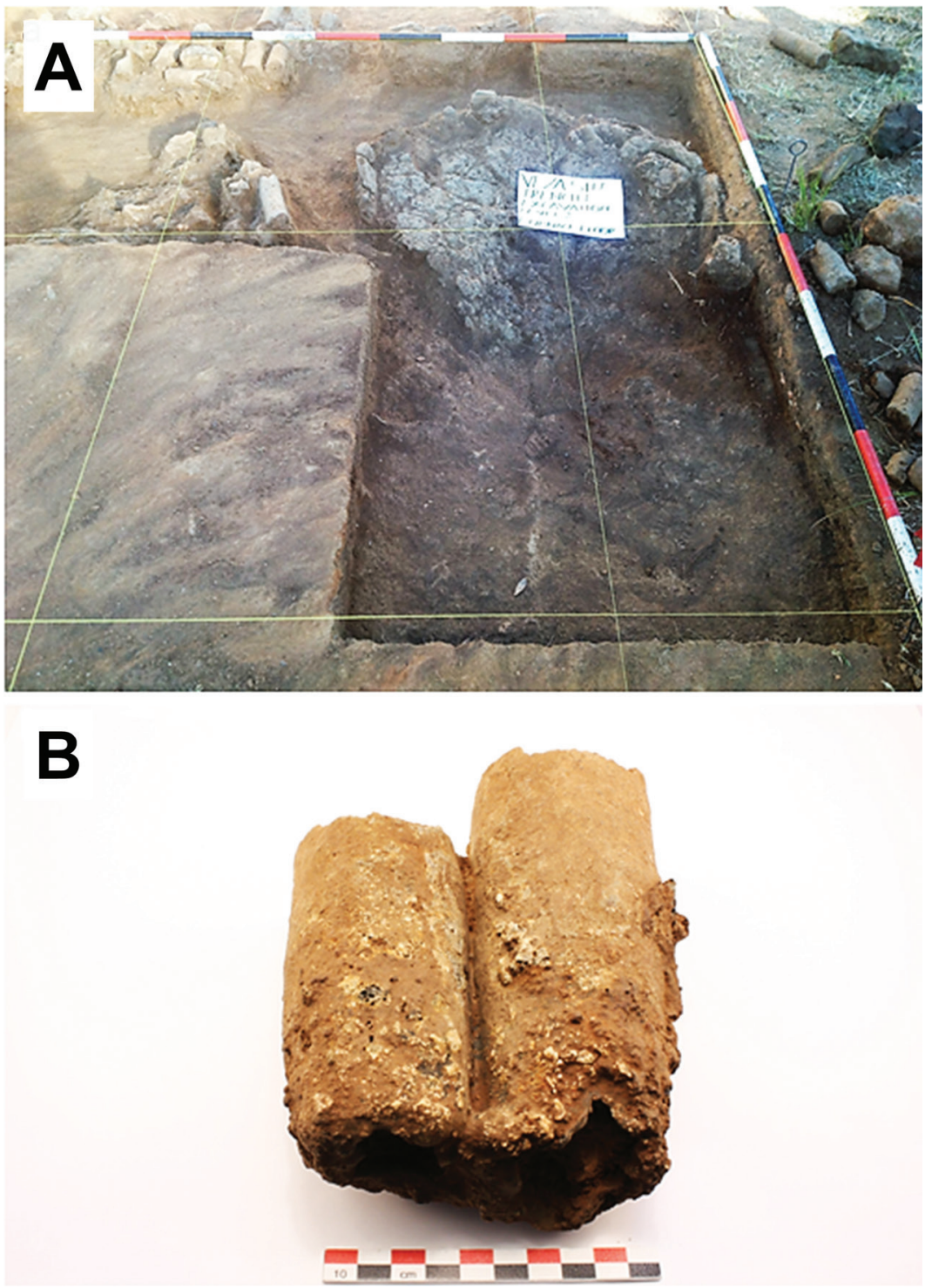

FIGURE 5.7 A circular furnace base (A) and double-fused tuyeres (B) from Veza site

making it likely that this could have been the floor of yet another linear furnace similar to the one uncovered at Mutevedzi site. Charcoal samples collected from a cluster of tuyeres on the floor of the furnace have been radiocarbon dated to $917 \pm 28 \mathrm{BP}$ (Ua-54055). The charcoal samples have been submitted also for trees species identification at the Witwatersrand University laboratories, to illuminate aspects of the exploitation and management of environmental resources in Great Zimbabwe's preindustrial iron metallurgy. 
Many of the tuyeres recovered from Veza A site were fused together in doubles, measuring about $3.5 \mathrm{~cm}$ internal diameter, $1.5 \mathrm{~cm}$ wall thickness and 20 $\mathrm{cm}$ length. The tuyeres show evidence of vitrification and melting at the distal end, which indicate that they were exposed to very high temperatures deep inside the furnace. The excavations also yielded very magnetic and heavily corroded slags with a curvilinear shape, which usually indicates smithing slag (Serneels and Perret, 2003; Miller et al., 2001). The occurrence of both smelting and smithing slags at the same location is a common encounter in African iron metallurgy, which makes it possible to reconstruct a fuller picture of the iron production and metal fabrication techniques.

\section{$2.6 \quad$ Veza B}

This smelting site lies about one kilometre up the Veza stream, southeast of Veza A site. It is located on the west side of a cluster of granite boulders about 2oom away from the stream. The site consists of large blocks of broken furnace walls measuring about $12 \mathrm{~cm}$ thick bearing visible finger impressions of the ironworkers who constructed the furnaces. Some of the furnace blocks show evidence of vitrification, indicative of the slag attacks on the fabric of the furnace wall. The site also has large heaps of tuyere pieces many of which are fused together in doubles (Figure 5.8). The tuyeres at the site show extensive evidence of melting at the mouth backwards due to intense heat in the furnace

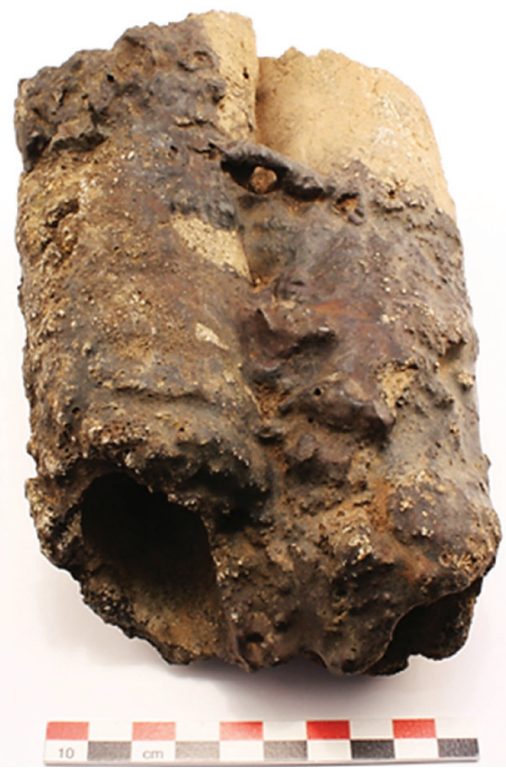

FIGURE 5.8 A double fused tuyeres from Veza B site 
where they were deeply inserted, leaving them significantly eroded and coated by slag on their external surfaces.

Many slag blocks at the site, alongside tuyeres and furnace blocks, were cleared away for agricultural purposes yearly ahead of the farming season since 1983 when the current landowner settled in the area, a possible indication of the large volumes of metallurgical wastes deposited at the site. The slags at the site have a grey streak and metallic lustre, showing low magnetism, porosity and no evidence of weathering, which suggests efficient slag-metal separation conditions in the furnace.

\section{$2.7 \quad$ Goose Bay}

David Collett was the first to investigate this site in 1986. It lies about 5 kilometers north of the Great Zimbabwe site. It is located on the western side of one of the numerous granite hills that are usually inundated by the waters of Lake Mutirikwi, which was built in the mid-2oth century. The site consists of broken furnace walls, dense slag and broken tuyere pieces. The tuyeres are flared on one end, indicating the use of forced-draft technology for iron-smelting at the site. Located in between the boulders that make up the granite hill are remains of a hut floor and pole impressed dhaka. Intra-site pedestrian surveys in 2013 around Goose Bay site, when Lake Mutirikwi was almost dry, recovered a clay phallic object, a possible crucible, potsherds and lower grinding stones, suggesting that the iron production activities at this site took place within a domestic context. The site was radiocarbon dated to $121 \pm 27$ (Ua-54O53) using charcoal stored in the Great Zimbabwe Conservation Centre from Collett's 1986 excavations, which places it in the terminal or post-Great Zimbabwe period (Chirikure et al., 2013).

\subsection{Sviba}

Sviba site lies about $5 \mathrm{~km}$ northeast of Great Zimbabwe and is located at the bottom of the western slope of Sviba hill. The site covers an area of about two hectares in which such iron production remains as furnace rubble, slag blocks and tuyere fragments are dispersed in small quantities. The largest slag block recovered at the site measures about $40 \mathrm{~cm}$ in diameter and is about $15 \mathrm{~cm}$ thick, and has a circular shape, suggestive of the use of low shaft furnaces at the site (Figure 5.9A). All the slag blocks at the site bear charcoal impressions, confirming the materials to be furnace slag. One of the tuyeres recovered at the site has a flared proximal, which is typically indicative of forced-draft air supply mechanisms at the site (Figure $5.9 \mathrm{~B}$ ). Surface slag and tuyere samples were collected for laboratory investigation meant to shed more light on the nature of the iron smelting processes practiced at the site. A second phase of 

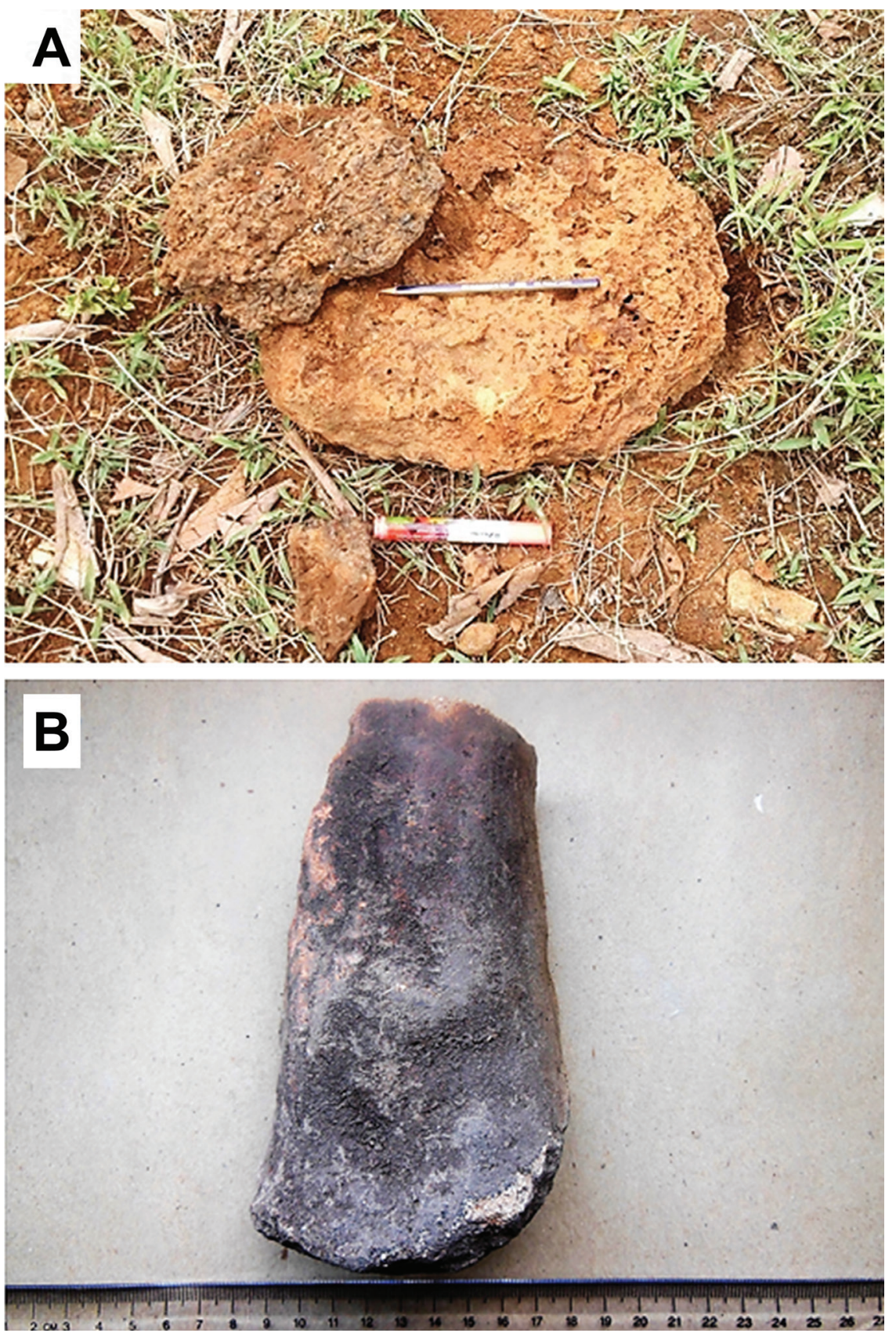

FIGURE 5.9 Archaeometallurgical materials from Sviba site: Dense furnace slag with plant impressions (A); Funnel shaped tuyere (B) 
archaeological investigations involving the excavation of the best-preserved sections of the site is necessary, which will most likely recover high quality material for chronometric dating and further archaeometallurgical analyses.

\section{$2.9 \quad$ Chronology}

Table 5.1 below presents a set of old and new radiocarbon dates reflecting a broad view of the chronology of the iron production sites around Great Zimbabwe. The circular and smaller furnace that Sinclair (1984) uncovered at Gokomere Mission was unequivocally driven by forced draft and is radiocarbon dated to 1800-1940 cal.AD (Pta-1975). According to Prendergast (1979: 118), this type of furnace was the most popular among 19th century Shona metallurgists. Earliest visitors to Great Zimbabwe in particular and southern Africa in general have provided detailed descriptions of this type of furnace, including its anthropomorphic features (Bent, 1893; Burke and Mauch, 1969; also Chirikure (2006) on the Njanja iron production).

TABLE 5.1 Radiocarbon dates of charcoal samples from furnace pits around Great Zimbabwe calibrated using OxCal 4.2 (Ramsey, 2009) and the SHCali3 curve (Hogg et al., 2013)

\begin{tabular}{|c|c|c|c|c|c|}
\hline Site name & Lab number & ${ }^{14} \mathrm{C}$ age $\mathrm{BP}$ & $\delta^{13} \mathrm{C} \%$ & $\begin{array}{l}\text { Calibrated date } \\
\text { range }(95 \% \\
\text { confidence) }\end{array}$ & Reference \\
\hline $\begin{array}{l}\text { Gokomere } \\
\text { Mission }\end{array}$ & Pta-1975 & $90 \pm 50$ & - & 180o-1940 cal. AD & Sinclair 1984 \\
\hline Goose Bay & Ua-54O53 & $121 \pm 27$ & -24.7 & 1696-18o7 cal. AD & Mtetwa 2017 \\
\hline Veza 1 & Ua-54055 & $917 \pm 28$ & $-25 \cdot 7$ & 1047-1227 cal. AD & Mtetwa 2017 \\
\hline Boroma & Ua-54052 & $1058 \pm 28$ & -26.3 & 986-1141 cal. AD & Mtetwa 2017 \\
\hline
\end{tabular}

\section{3}

\section{Discussion}

As highlighted in the introduction, the key question of this paper concerns the possibility of illuminating the presence of remarkable technological diversity and variability in the iron industry of Great Zimbabwe during precolonial times. The foregoing section presented a growing corpus of various furnace designs, different slag types and tuyeres, some fused in multiples. 


\section{1 $\quad$ Furnaces}

The fieldwork results presented above, in conjunction with written sources (Bent, 1892; Burke and Mauch, 1969), indicate the use of low forced draft and high natural draft furnaces in the area. The internal diameters of furnaces discovered in the Chigaramboni hills, Mashava and Boroma, which measured between 1.0 and $1.4 \mathrm{~m}$, fall within a range usually associated elsewhere with high natural draft furnaces (Halaand and Shinnie, 1985; Killick, 1990; Mapunda, 1995). The growing evidence of natural draft iron smelting furnaces in large clusters around the Great Zimbabwe area is particularly noteworthy. Their occurrence in large clusters, as observed at Chigaramboni and Mashava sites, offers a critical opportunity to rethink the scales of iron production and the size of the market that would have consumed such quantities of iron.

Due to insufficient knowledge of African technology, it was generally assumed that the high natural draft furnaces were largely limited to west, east and central Africa and were not popular in regions that lie south of the Zambezi River (Van der Merwe, 1980; Kense, 1985; Halaand and Shinnie, 1985). Cline (1937), for instance, thinks that this geographical distribution of natural draft furnaces north of the Zambezi River coincided with areas known to have been hubs of extensive trade networks from around AD 16oo. Fagan (1961) also thinks that natural draft furnaces were well adapted to the northerly regions' large-scale trade in iron by their capacity and, presumably, the quality of the resultant metal. Curiously, Cline and Fagan were undoubtedly aware of the place of Great Zimbabwe in the Indian Ocean and central African trade systems, which should naturally have stimulated their attention towards proper consideration of its archaeometallurgy. Nevertheless, they maintained that the low shaft furnaces, driven by forced-draft, was the 'classic Rhodesian type', which was regarded as lagging behind technologies further north.

Importantly, new radiocarbon dates of $1058 \pm 28$ BP (Ua-54052) and $917 \pm 28$ вр (Ua-54055) from the respective sites of Boroma and Veza 1 suggest that the Great Zimbabwe area carried perhaps some of the earliest natural draft iron smelting sites than areas north of the Zambezi River. So far, the earliest known natural draft iron smelting furnaces were discovered in northern Zimbabwe by Prendergast $(1979,1975)$ and fall in the 14th century AD calibrated radiocarbon dates. As pointed out by Ndoro (1994), there is no ethnographic and written evidence for natural draft technology in the Great Zimbabwe area, or elsewhere in southern Africa as is the case north of the Zambezi River (see Killick, 199o; Mapunda, 1995). On the basis of these two recent dates and the criterion of tuyeres fused in multiples from Boroma and Veza 1 sites, this paper proposes that natural draft furnaces were possibly earlier in southern Africa where they developed as a component of the technological transformations 
related to the Great Zimbabwe Culture. More radiometric dates from such sites as Chigaramboni and Mashava with tuyeres fused in as many as ten pieces will shed more light on the early history of this technique in African metallurgy.

Another important example of furnace type from Great Zimbabwe is the rectangular furnace base uncovered at Mutevedzi. So far, there are few reports of a similar design in the archaeometallurgical record of sub-Saharan Africa (Thebe et al., 2016). Its dimensions of about $2 \times 1$ metres suggest that the furnace would have been well adapted for large-scale iron smelting processes. Once again, the presence of tuyeres fused in multiples of three at the site suggests that this was yet another variant of natural draft technology. Well-researched examples of metallurgical furnaces of a rectangular or linear design have been reported from Sri Lanka, Burma, Cambodia and Japan (Juleff, 20o9; 1996), but also in Egypt (Scheel, 1989). The Sri Lankan rectangular furnaces, dated to the end of the first millennium AD, were driven by strong monsoon winds to produce high quality steel (Juleff, 1996; Tabor, Molinari, and Juleff, 2005). A more similar example to the Great Zimbabwe case is the Burmese furnaces, which operated by natural draft using as many as twenty tuyeres on one of the long sides of the rectangular furnace. The Burmese furnaces have been dated to the second half of the second millennium AD. There is also the Cambodian linear furnace technology, which is operated by forced-draft, with as many as twenty-three tuyeres on each of the two long sides (Juleff, 2009).

Unfortunately, the Great Zimbabwe furnace was demolished to ground level where the remaining rectangular wall stands barely $10 \mathrm{~cm}$ high, showing no visible tuyere holes. Juleff has suggested that elements of the Sri Lankan linear furnace technology were possibly transmitted to other regions of southern Asia such as Burma, Cambodia and Japan within trade contexts (Juleff, 2009). Likewise, it is reasonable to ask whether elements of the Southern Asian linear furnace technology were transmitted to southern Africa within contexts of the Indian Ocean trade connections. Already, the introduction of tin, gold and bronze in southern Africa in the early second millennium AD, and the use of such infrastructure as flat-based crucibles at Great Zimbabwe is regarded as indicative of cross-borrowing of technology (Summers, 1969). Increased archaeological fieldwork in southern Africa including the adjacent island of Madagascar, where local histories of iron metallurgy remain poorly illuminated, will shed more light on the origins or spread of technologies that were present in Zimbabwe by the mid-second millennium AD. Investigations are underway to obtain radiometric dates for the Great Zimbabwe linear furnace technology and more research, which may include experimental archaeology, is required to understand the mechanics of smelting iron in a rectangular furnace. 


\subsection{Tuyeres}

Archaeological fieldwork in the Great Zimbabwe landscape encountered two types of tuyeres, commonly known to have penetrated the furnace from around the base. Clearly, the two types of tuyeres indicate significant technological variation in Great Zimbabwe synchronically and diachronically. Flared tuyeres typically functioned with bowl and low shaft furnaces, which are generally viewed as the earliest smelting techniques (Chirikure et al., 2009; Friede, 1979; Miller and Van Der Merwe, 1994). The technique was evidently the only one in use, at least in southern Africa during the 19th and early 2oth centuries as attested by written accounts, archaeological research as well as local tradition (Chirikure, 2006; Prendergast, 1979; Sinclair, 1984).

The advent of a smelting technique, which used multiple tuyeres to drive high natural draft furnaces, represents a significant turning point in the history of not just iron metallurgy in southern Africa as a region, and Great Zimbabwe specifically, but in the broader society. The calibrated radiocarbon dates for two of the sites with multiple fused tuyeres fall between the 1oth and 12th centuries AD. The new dates suggest that the advent of high natural draft furnaces would have been one component of a much broader socio-economic, political and technological transformation observed in the archaeological record of southern Africa from the late first millennium AD. Phillipson (2005) posits that from around the first and second millennium AD changeover, there was a sudden restructuring of the entire range of daily activities associated with the specialised production of artifacts and materials. In architecture, which has received relatively more research attention, these changes were characterized by so much experimentation and change in the organization of space as well as new materials and techniques. In the archaeology of Great Zimbabwe, archaeologists have robustly pursued these major technological transformations more in the area of architectural innovations (see, for example Chipunza, 1994), overlooking possible developments in, for instance, metallurgical ingenuity. The new evidence presented in this paper provides perhaps the first detailed picture of other technological innovations associated with Great Zimbabwe outside drystone architecture, a well-known example in southern African archaeology. The archaeometallurgical data provides more evidence useful for further deconstruction of earlier stereotypes of uniformity, stagnation and lack of sophistication in African technology as has been demonstrated in other regions of sub-Saharan Africa (Killick and Fenn, 2012; Killick, 2015).

\subsection{Slags}

Initially, the absence of ethnographic and written evidence for the tapping of slag in Zimbabwe was taken as evidence for the absence of the slag tapping 
technique between the Zambezi and Limpopo Rivers (see for example Miller and Van der Merwe 1994). Nevertheless, archaeological research has attested the use of the technique at Baranda, a Zimbabwe Culture capital of the Mutapa State in northern Zimbabwe (Chirikure and Rehren, 2006). The tuyeremoulded slags and some with flat bottoms bearing sand impressions excavated at Mashava site clearly demonstrate that the technique of tapping out of the furnace, to allow for longer hours of smelting iron and improving its quality, was perhaps more widespread in Zimbabwe. It was certainly not limited to northern areas of Zimbabwe, where it was first recorded (Prendergast, 1979). Archaeological iron smelting slags further south of Zimbabwe were assumed to have always originated in non-tapping bloomery furnaces. Miller and Van der Merwe (1994), for instance, argue that there was no record of liquid slags having been deliberately drained from the operational chamber of the furnace during smelting. On the contrary, the tuyere-moulded slags from Mashava site even suggest that some tuyeres may have been specially positioned to function as air inlets first and slag outlets later on during the smelting process. Slag tapping using tuyeres at the rake hole is ethnographically confirmed among the Fipa of southwestern Tanzania (Mapunda, 2010), and may actually have been practiced more widely and much earlier in Africa.

Other macroscopic attributes of slags from the Great Zimbabwe landscape give interesting hints about the raw materials, fluxing practices, as well as slagmetal separation, reflecting the varied decisions and choices made by the iron smelters (Rehren et al., 2007). For instance, many of the recovered furnace slag samples had evidence of plant impressions (see Table 5.2), indicative of the different types of plant materials charged in the furnace as part of the smelting recipes.

Most of the recovered slag samples had very low magnetism, which typically reflects efficient slag-metal separation (Miller et al., 2001). However, there were other slag samples from within the same sites, which had high magnetism, exhibiting a metallic lustre and grey streak. Some of these highly magnetic samples are possibly smithing slags, which would imply that both primary metal extraction and secondary processing took place at the same location such as Boroma.

The evidence of preindustrial iron metallurgy in the wider archaeological landscape of Great Zimbabwe presented in this paper suggest that the area carried a remarkable variety of iron production technologies over time. Instead of a 
TABLE 5.2 A summary of macroscopic attributes of slag samples and bloom analyzed with the aid of optical and electron microscopy on polished thin sections

\section{Sample Material Morphology Lustre Porosity Magnetism Inclusions/ Streak/ Impressions Color}

\begin{tabular}{|c|c|c|c|c|c|c|c|}
\hline Ması & $\begin{array}{l}\text { Smelting } \\
\text { slag }\end{array}$ & Cylindrical & $\begin{array}{l}\text { Metallic } \\
\text { section }\end{array}$ & Low & Nil & None & $\begin{array}{l}\text { dark- } \\
\text { brown }\end{array}$ \\
\hline Mas2 & $\begin{array}{l}\text { Smelting } \\
\text { slag }\end{array}$ & Flat & $\begin{array}{l}\text { Metallic } \\
\text { section }\end{array}$ & Low & Nil & ground floor & $\begin{array}{l}\text { red- } \\
\text { brown }\end{array}$ \\
\hline Mas3 & Bloom & Amorphous & $\begin{array}{l}\text { glass } \\
\text { section }\end{array}$ & Low & Very high & None & $\begin{array}{l}\text { Brown } \\
\text { cortex }\end{array}$ \\
\hline Mutı & $\begin{array}{l}\text { Smelting } \\
\text { slag }\end{array}$ & Quadrilateral & ceramic & High & Low & $\begin{array}{l}\text { plant } \\
\text { impressions }\end{array}$ & Brown \\
\hline Borı & $\begin{array}{l}\text { Smelting } \\
\text { slag }\end{array}$ & Amorphous & ceramic & Medium & Low & $\begin{array}{l}\text { plant } \\
\text { impressions }\end{array}$ & Brown \\
\hline Bor2 & $\begin{array}{l}\text { Smelting } \\
\text { slag }\end{array}$ & Elongated & ceramic & Medium & Low & $\begin{array}{l}\text { plant } \\
\text { impressions }\end{array}$ & Brown \\
\hline Bor3 & $\begin{array}{l}\text { Smelting } \\
\text { slag }\end{array}$ & Amorphous & ceramic & Medium & Low & Nil & Brown \\
\hline Svi1 & $\begin{array}{l}\text { Smelting } \\
\text { slag }\end{array}$ & Amorphous & ceramic & Medium & Low & $\begin{array}{l}\text { plant } \\
\text { impressions }\end{array}$ & Brown \\
\hline VezA1 & $\begin{array}{l}\text { Smithing } \\
\text { slag }\end{array}$ & Amorphous & $\begin{array}{l}\text { Metallic } \\
\text { section }\end{array}$ & Low & High & $\begin{array}{l}\text { Vitrified } \\
\text { ceramic }\end{array}$ & Brown \\
\hline VezA2 & $\begin{array}{l}\text { Smithing } \\
\text { slag }\end{array}$ & $\begin{array}{l}\text { Concave/ } \\
\text { Convex }\end{array}$ & Greasy & Low & Very high & None & Brown \\
\hline VezB1 & $\begin{array}{l}\text { Smelting } \\
\text { slag }\end{array}$ & Amorphous & Greasy & High & Low & $\begin{array}{l}\text { Plant } \\
\text { impressions }\end{array}$ & Brown \\
\hline Chis & $\begin{array}{l}\text { Smelting } \\
\text { slag }\end{array}$ & Plano-convex & Greasy & Medium & Low & $\begin{array}{l}\text { Floor, plant } \\
\text { impressions }\end{array}$ & Brown \\
\hline Chi2 & $\begin{array}{l}\text { Smithing } \\
\text { slag? }\end{array}$ & Amorphous & Metallic & Low/ & $\begin{array}{l}\text { Very } \\
\text { magnetic }\end{array}$ & None & Grey \\
\hline Goo1 & $\begin{array}{l}\text { Smithing } \\
\text { slag? }\end{array}$ & Amorphous & $\begin{array}{l}\text { Metallic } \\
\text { section }\end{array}$ & High & High & None & Brown \\
\hline
\end{tabular}

dearth of archaeometallurgical debris as previously assumed, the area has concentrations of iron production sites intimately correlated with the mountain ranges surrounding the urban centre, whose banded ironstones would have provided quality iron ores. These remains of iron production reflect a wide range of novel designs and processes of metal extraction in the form of natural 
draft furnaces, tap slags and a rectangular furnace design previously unknown in the iron metallurgy of southern Africa. The presence of huge natural draft furnaces in the Chigaramboni hills, Mashava, Boroma, Mutevedzi and Veza sites represents a significant change not just in the technology of Great Zimbabwe, but its social, economic, as well as environmental systems and processes as a whole.

The radiocarbon dates obtained for two of the recorded iron production sites associated with multiple fused tuyeres suggest that the Great Zimbabwe area has the earliest evidence of natural draft technologies in southern Africa. The dates, which fall in the beginning of the second millennium AD, offer a new chronological frame to rethink the distribution and circumstances surrounding the development of natural draft furnaces. Because of their contemporaneity and proximity to the urban centre, it is not unreasonable to associate the newly dated iron production sites with the metal extraction strategies of Great Zimbabwe, which was at its peak between the 12th and 16th centuries AD. This new picture of contemporaneity, however, requires more refinement using high quality material for chronometric dating and archaeometallurgical analyses. Lead isotope and elemental analyses of metal objects and the geochemistry of the exploited iron ores (Ling et al., 2014), for instance, have the potential to yield insights into the connections and disconnections between the Great Zimbabwe urban centre and the metallurgical resources and technologies across its wider archaeological landscape.

\section{Acknowledgements}

The Rydberg Foundation and Societas Archaeologica Upsaliensis (SAU) at Uppsala University funded the fieldwork reported in this paper. E.M. would like to thank the Executive Directorate and staff of National Museums and Monuments of Zimbabwe (NMMZ) for the research permit and support for this study. E.M. is equally thankful to the archaeology students and staff from Great Zimbabwe University, Midlands State University and the University of Zimbabwe whose participation in the fieldwork made this research successful.

\section{References}

Bandama, F., Moffett, A. J., Thondhlana, T. P., and Chirikure, S. 2016. The production, distribution and consumption of metals and alloys at Great Zimbabwe. Archaeometry 58(9):164-181. 
Bandama, F., Moffett, A.J., and Chirikure, S. 2017. Typological and technological attributes of metallurgical crucibles from Great Zimbabwe (1000-1700 CE)'s legacy collections. Journal of Archaeological Science: Reports 12: 646-657.

Bannerman, J.H. 1982. Ecological and other factors in the rise and fall of the Great Zimbabwe state. Paper presented at "Conference in Zimbabwean History: Progress and Development" 25-27 August 1982, University of Zimbabwe: Harare, Zimbabwe.

Bent, J.T. 1892. The ruins of Mashonaland, and explorations in the country. Proceedings of the Royal Geographical Society and Monthly Record of Geography 14(5): 273-298.

Bronk R.C. 2009. Bayesian analysis of radiocarbon dates. Radiocarbon 51(1): 337-36o.

Brown, J. 1973. Early iron production. Rhodesian Prehistory 7: 3-7.

Burke, E., and Karl Mauch. 1969. The journals of Carl Mauch: his travels in the Transvaal and Rhodesia 1869-1872. National Archives of Rhodesia.

Chikumbirike, J. 2014. Archaeological and palaeoecological implications of charcoal assemblages dated to the Holocene from Great Zimbabwe and its hinterland. Unpublished PhD Thesis. University of the Witwatersrand: Johannesburg, South Africa.

Childs, S.T., and David, K. 1993. Indigenous African metallurgy: nature and culture. Annual Review of Anthropology 22: 317-337.

Chipunza, K.T. 1994. A diachronic analysis of the architecture of the Hill Complex at Great Zimbabwe. Vol. 8. Unpublished Master Thesis. Uppsala University, Department of Archaeology and Ancient History: Uppsala, Sweden.

Chirikure, S., and Bandama, F. 2014. Indigenous African furnace types and slag composition-is there a correlation? Archaeometry 56(2): 296-312.

Chirikure, S. 2005. Iron production in Iron Age Zimbabwe: stagnation or innovation? Unpublished PhD Thesis. University of London: London, UK.

Chirikure, S. 2006. New light on Njanja iron working: towards a systematic encounter between ethnohistory and archaeometallurgy. South African Archaeological Bulletin $61(184): 142-151$.

Chirikure, S. 2007. Metals in society: iron production and its position in Iron Age communities of Southern Africa. Journal of Social Archaeology 7(1): 72-10o.

Chirikure, S. 2014. Land and sea links: 1500 years of connectivity between Southern Africa and the Indian Ocean rim regions, AD 700 to 1700. African Archaeological Review 31(4): 705-724.

Chirikure, S. 2015. Metals in past societies: a global perspective on indigenous African metallurgy. Springer: New York, USA.

Chirikure, S., Burrett, R., and Heimann, R.B. 2009. Beyond furnaces and slags: a review study of bellows and their role in indigenous African metallurgical processes. Azania: Archaeological Research in Africa 44(2): 195-215.

Chirikure, S., Manyanga, M., Pikirayi, I., and Pollard, M. 2013. New pathways of sociopolitical complexity in Southern Africa. African Archaeological Review 30(4): 339-366. 
Chirikure, S., Moultrie, T., Bandama, F., Dandara, C., and Manyanga, M. 2017. What was the population of Great Zimbabwe (CE10oo-18oo)? PloS One 12(6): eo178335.

Chirikure, S., and Pikirayi, I. 2008. Inside and outside the dry stonewalls: revisiting the material culture of Great Zimbabwe. Antiquity 82(318): 976-993.

Chirikure, S., Pollard, M., Manyanga, M., and Bandama, F. 2013. A Bayesian chronology for Great Zimbabwe: re-threading the sequence of a vandalised monument. Antiquity 87(337): 854-872.

Chirikure, S., and Rehren, T. 2006. Iron smelting in precolonial Zimbabwe: evidence for diachronic change from Swart Village and Baranda, northern Zimbabwe. Journal of African Archaeology 4(1): 37-54.

Cline, W. B. 1937. Mining and metallurgy in Negro Africa. Menasha, WI: George Banta.

De Caro, T., Riccucci, C., Parisi, E.I., Renzulli, A., Del Moro, S., Santi, P., and Faraldi, F. 2013. Archaeometallurgical studies of tuyeres and smelting slags found at Tharros, northwestern Sardinia, Italy). Applied Physics A: Materials Science and Processing 113(4): 933-943.

Fagan, B. 1961. Pre-European ironworking in Central Africa with special reference to Northern Rhodesia. Journal of African History 2(2): 199-210.

Friede, H.M. 1972. Iron-smelting furnaces. The South African Archaeological Bulletin. https://doi.org/10.2307/3888519.

Friede, H.M. 1979. Iron-smelting furnaces and metallurgical traditions of the South African Iron Age. Journal of the South African Institute of Mining 8: 372-381.

Halaand, R., and Shinnie. P.L. 1985. African iron working, ancient and traditional. Norwegian University Press: Oslo, Norway.

Hall, R.N. 19o9. Prehistoric Rhodesia: An examination of the historical, ethnological and archaeological evidences as to the origin and age of the rock mines and stone buildings, with a Gazetteer of Medieval South-East Africa, 915 AD to 1760 AD, and the countries of the Monomotapa, Manica, Sabia, Quiteve, Sofala and Mozambique. George W. Jacobs \& Company: Philadelphia, USA.

Hegel, G.W.F. 1995. Lectures on the history of philosophy: Greek Philosophy to Plato Vol. 1. University of Nebraska Press: Lincoln, USA.

Herbert, E.W. 1984. Red gold of Africa: copper in precolonial history and culture. University of Wisconsin Press: Madison, USA.

Herbert, E.W. 1996. Metals and power at Great Zimbabwe. Aspects of African Archaeology, 641-647.

Hogg, A.G., Hua, Q., Blackwell, P.G., Niu, M., Buck, C.E., Guilderson, T.P., Heaton, T.J. et al., 2013. SHCalı3 southern hemisphere calibration, o-50,00o years cal BP. Radiocarbon 55(4): 1889-1903.

Hume, D. 1758. Essays and treatises on several subjects. A. Millar; and A. Kincaid and A. Donaldson, at Edinburgh. 
Humphris, J., Martinon-Torres, M., Rehren, T., and Reid, A. 2009. Variability in single smelting episodes: a pilot study using iron slag from Uganda.Journal of Archaeological Science 36(2): 359-369.

Juleff, G. 20og. Technology and evolution: a root and branch view of Asian iron from first-millennium BC Sri Lanka to Japanese steel. World Archaeology 41(4): 557-577.

Juleff, G. 1996. An ancient wind-powered iron smelting technology in Sri Lanka. Nature 379(656o): 6o-63.

Kense, F.J. 1985. The initial diffusion of iron to Africa. In: Halaand R., and Shinnie, P.L. (eds) African Iron Working: Ancient and Traditional. Norwegian University Press: Oslo, Norway, pp. 1-27.

Killick, D. 1991. A little-known extractive process: iron smelting in natural-draft furnaces. JOM Journal of the Minerals Metals and Materials Society 43(4): 62-64.

Killick, D. 2015. Invention and innovation in African iron-smelting technologies. Cambridge Archaeological Journal 25(1): 307-319.

Killick, D. 1990. Technology in its social setting: bloomery iron smelting at Kasungu, Malawi, 1860-1940. Unpublished PhD Thesis. Yale University: Connecticut, USA.

Ling, J., Stos-Gale, Z., Grandin, L., Billström, K., Hjarthner-Holdar, E., and Persson, P. 2014. Moving metals II: provenancing Scandinavian Bronze Age artefacts by lead isotope and elemental analyses. Journal of Archaeological Science 41(1): 106-132.

Lister, L.A. 1987. The erosion surfaces of Zimbabwe. Zimbabwe Geological Survey 9०: 163 .

Mapira, J. 2012. Masvingo City's SIMBI iron ore processing plant: socioeconomic benefits versus environmental threats. Journal of Social Development in Africa 27(2): $165^{-188 .}$

Mapunda, B.B. 1995. An archaeological view of the history and variation of ironworking in southwestern Tanzania. Unpublished PhD Thesis. University of Florida: Gainesville, USA.

Mapunda, B.B. 2010. Contemplating the Fipa iron technology. Fountain Publishers: Kampala, Uganda.

Miller, D. 2002. Smelter and smith: Iron Age metal fabrication technology in Southern Africa. Journal of Archaeological Science 29(10): 1083-1131.

Miller, D., Killick, D., and van der Merwe, N.J. 2001. Metal working in the Northern Lowveld, South Africa, AD 100o-189o. Journal of Field Archaeology 28(3-4): 401-417.

Miller, D., and Van Der Merwe, N.J. 1994. Early metal working in Sub-Saharan Africa: a review of recent research. The Journal of African History 35(1): 1-36.

Mitchell, P. 2002. The archaeology of Southern Africa. Cambridge University Press: Cambridge, USA.

Moffett, A.J., and Chirikure, S. 2016. Exotica in context: reconfiguring prestige, power and wealth in the Southern African Iron Age. Journal of World Prehistory 29(4): $337-382$. 
Mtetwa, E. 2011. An archaeological perspective of iron production in south-central Zimbabwe. Unpublished Master Thesis. University of Dar es Salaam: Dar es Salaam, Tanzania.

Mtetwa, E., 2017. Technology, ideology and environment: the social dynamics of iron metallurgy in Great Zimbabwe, AD goo to the present. Published PhD Thesis. Uppsala University, Department of Archaeology and Ancient History: Uppsala, Sweden.

Mtetwa, E., Maposa, Y.C., Manyanga, M., and Chirikure, S. 2017. When the smith is a woman: innovation, improvisation and ambiguity in the organization of African metallurgy. In: Chirikure, S., and Manyanga, M. (eds) Archives, Objects, Places and Landscapes: multidisciplinary approaches to decolonised Zimbabwean pasts, pp 295-318.

Ndoro, W. 1994. Natural draught furnaces south of the Zambezi River. Zimbabwean Prehistory 21: 29-32.

Ndoro, W. 2001. Your monument our shrine: the preservation of Great Zimbabwe. Published PhD Thesis. Uppsala University, Department of Archaeology and Ancient History: Uppsala, Sweden.

Phimister, I.R. 1974. Ancient mining near Great Zimbabwe. Journal of the Southern African Institute of Mining and Metallurgy 74(6): 233-237.

Phimister I.R. 1976. Precolonial gold mining in southern Zambezia: a reassessment. African Social Research 21: 1-30.

Pikirayi, I. 2013. Stone architecture and the development of power in the Zimbabwe Tradition AD 1270-1830. Azania: Archaeological Research in Africa 48(2): 282-300.

Pikirayi, I. 2017. Trade, globalisation and the archaic state in Southern Africa.Journal of Southern African Studies 43(5): 879-893.

Pikirayi, I., Sulas, F., Musindo, T.T., Chimwanda, A., Chikumbirike, J., Mtetwa, E., Nxumalo, B., and Sagiya, E.M. 2016. Great Zimbabwe's water. Wiley Interdisciplinary Reviews: Water 3(2): 195-210.

Prendergast, M.D. 1975. A new furnace type from the Darwendale Dam Basin. Rhodesian Prehistory 7(14): 16-20.

Prendergast, M.D. 1974. Research into the ferrous metallurgy of Rhodesian Iron Age Societies. Journal of the South African Institute of Mining and Metallurgy 74(6): 254-264.

Prendergast, M.D. 1979. Iron Age settlement and economy in part of the Southern Zambezian Highveld. The South African Archaeological Bulletin 34(130): 111-119.

Pwiti, G. 1991. Trade and economies in Southern Africa: the archaeological evidence. Zambezia XVIII (II): 119-129.

Rehder, J.E. 2000. Mastery and uses of fire in antiquity. McGill-Queen's University Press. Rehren, T., and Charlton, M., Chirikure, S., Humphris, J., Ige, A., and Veldhuijzen, H.A. 2007. Decisions set in slag: the human factor in African iron smelting. In: Metals and Mines: Studies in Archaeometallurgy, 211-218.

Roper, H.T. 1966. Rise of Christian Europe. Thames and Hudson: London, UK. 
Scheel, B. 1989. Egyptian metalworking and tools. Shire Publications: Oxford, UK.

Serneels, V., and Perret, S. 2003. Quantification of smithing activities based on the investigation of slag and other material remains. Archaeometallurgy in Europe 1: 469-478.

Sinclair, P.J.J. 1987. Space, time and social formation: a territorial approach to the archaeology and anthropology of Zimbabwe and Mozambique c o-1700 AD. Published PhD Thesis. Uppsala University: Uppsala, Sweden.

Sinclair, P.J.J. 1984. Rescue excavation of a furnace at Gokomere Mission, Zimbabwe. National Museums and Monuments of Zimbabwe.

Smith, M.E., 2004. The archaeology of ancient state economies. Annual Review of Anthropology 33(1): 73-102.

Summers, R. 1969. Ancient mining in Rhodesia. National Museums of Rhodesia, Museum memoir, National museums of Rhodesia, 3 (Museum Memoir): 236.

Swan, L.M. 2008. Minerals and managers: production contexts as evidence for social organization in Zimbabwean prehistory. Published PhD Thesis. Uppsala University: Uppsala, Sweden.

Tabor, G.R., Molinari, D., and Juleff, G. 2005. Computational simulation of air flows through a Sri Lankan wind-driven furnace. Journal of Archaeological Science 32(5): $753-766$.

Tarikhu Farrar, V. 2020. Precolonial African material culture: combatting stereotypes of technological backwardness. Rowman \& Littlefield: Maryland, USA.

Thebe, P.C., Huffman, T.N., Watkeys, M.K. and Tarduno, J.A., 2016. Ancient metallurgy in the Tswapong Hills, Botswana: a preliminary report on archaeological context. Southern African Humanities 28(1):119-133.

Trigger, B.G. 2003. Understanding early civilizations: a comparative study. Cambridge University Press: New York, USA.

Van der Merwe, N.J. 1980. The advent of iron in Africa. West African Journal of Africa $5: 1-10$.

Wood, M. 2012. Interconnections: glass beads and trade in Southern and Eastern Africa and the Indian Ocean-7th to 16th centuries AD. sPublished PhD Thesis. Uppsala University: Uppsala, Sweden. 